\title{
Application of the accelerated learning cycle, brain- based learning model and direct instruction model toward mathematical reasoning in terms of mathematical communication
}

\author{
Arie Purwa Kusuma ${ }^{1}$, Nurina Kurniasari Rahmawati ${ }^{1}$, Ramadoni ${ }^{2}$ \\ ${ }^{1}$ STKIP Kusuma Negara Jakarta, Indonesia \\ ${ }^{2}$ National Dong Hwa University, Taiwan \\ $\triangle$ arie_pk@stkipkusumanegara.ac.id*
}

Article Information

Submitted April 04, 2019

Revised April 15, 2020

Accepted April 20, 2020

Keywords

Accelerated Learning Cycle;

Brain-based learning model;

Mathematical Communication;

Mathematical Reasoning;

Powtoon.

\begin{abstract}
The students' mathematical reasoning and mathematical communication abilities are influenced by several factors such as the use of learning models used by teachers in learning. The use of appropriate learning models can increase students' mathematical communication abilities and reasoning. This study aims to determine the effect of the Accelerated Learning Cycle, Brain-based learning model and Direct Instruction learning models on students' mathematical reasoning abilities seen from their communication abilities. This is a quasi-experimental research. The data were analyzed using analysis of variance with unequal cells. This study concludes that, first, Accelerated Learning Cycle provides better mathematical reasoning abilities than the Brain-based learning model and the Direct Instruction learning model and Brain-based learning model provide better mathematical reasoning abilities than the Direct Instruction learning model. Second, students who have high mathematical communication abilities have better mathematical reasoning than students with moderate or low mathematical communication abilities, students who have medium communication abilities have better mathematical reasoning than students with low mathematical communication abilities.
\end{abstract}

\section{INTRODUCTION}

Mathematics always be one of the subjects taught from primary, secondary, and tertiary education (Syazali, 2015). Mathematics has become an important element in developing science and technology (Wulandari et al, 2016). However, students still think that learning mathematics is boring (Sari et al, 2016). The teacher-centered learning process does not provide an opportunity for students to be active in teaching and learning activities (Badrun \& Hartono, 2013). Difficulties in learning mathematics are seen when students are given questions in the form of reasoning. The level of mastery of the material regarding reasoning is still categorized as low. This means that mathematics lessons related to the ability to recognize and communicate still need special attention because students can exchange ideas and at the same time clarify the understanding and knowledge they gain in learning.

In building reasoning and strategic thinking, teachers must pay attention to in learning mathematics, namely: the type of mathematical thinking must be relevant to the students, the type of teaching materials, class management, the role of the teacher, as well as student autonomy in thinking and doing activities. The application of an appropriate learning model is possible to improve the reasoning ability of students. Currently, the learning model used at the schools known as the direct learning model (direct instruction). Using this model, teacher

Kusuma, A. P., Rahmawati, N. K., \& Ramadoni, R. (2020). The application of the accelerated learning cycle, brainbased learning model, and direct instruction model toward mathematical reasoning in terms of mathematical communication. Al-Jabar: Jurnal Pendidikan Matematika, 11(1), 21-28. 
Cooperative learning is a learning model based on students actively involved in sharing ideas and working together to complete academic tasks (Zakaria \& Ihsan, 2007). The cooperative models used in this research were Accelerated Learning Cycle, Brain-based learning model, and Direct Instruction. Accelerated Learning Cycle has the principle that learning also involves the whole mind and body, learning is creative not consuming, cooperation can help the learning process well, learning takes place at many levels simultaneously, learning comes from doing the work itself, supporting positive emotions that help to learn, as well as the brain that can absorb information directly and automatically. This is the principle of a good learning model to apply. This study aimed to describe which is better between the Accelerated Learning Cycle, Brain-based learning model, and Direct Instruction on students' mathematical reasoning in terms of mathematical communication.

Several previous studies have discussed how to apply the models (Amelia, 2015; Awaliyah, 2016) and research in improving mathematical reasoning abilities and mathematical communication (Adesty et al, 2014; Ambarwati et al, 2015; Andrianti et al, 2016; Ariany \& Dahlan, 2017; Atsnan, 2015; Diandita et al, 2017; Fisher, 2017; Hartati \& Suyitno, 2015; Indriani, 2018; Khamid \& Santosa, 2016; Nopitasari, 2015; Nurhayati, 2018; Nuriadin, 2015; Putra, 2016; Putra, 2015; Setiawan, 2016; Solekha et al, 2013; Sumartini, 2018; Supriadi \& Damayanti, 2016; Wibowo, 2017; Harahap, 2014). Research comparing the application of Accelerated Learning Cycle, Brain-based learning model and Direct Instruction on mathematical reasoning abilities in terms of students' mathematical communication abilities. Based on previous research, the novelty of this research was focused on the influence of the Accelerated Learning Cycle, Brain-based learning model, and Direct Instruction on students' mathematical reasoning abilities seen from their communication abilities. So, the purpose of this study was to determine the effect of the Accelerated Learning Cycle, Brain-based learning model, and Direct Instruction on students' mathematical reasoning abilities seen from the students' communication abilities.

\section{METHODS}

The research method used was quasi-experimental research. This study used a $3 \times 3$ factorial design through a two-way ANAVA technique with unequal cells because this study intended to examine simultaneously the 3 treatments of learning models in groups that were different in terms of mathematical communication abilities levels. The research design can be seen in Table 1.

Table 1. the Design of $3 \times 3$ Factorial Research

\begin{tabular}{lccc}
\hline \multicolumn{1}{c}{ Leaning Model } & \multicolumn{3}{c}{ Mathematical Communication Abilities } \\
& High $\left(\mathbf{y}_{\mathbf{1}}\right)$ & Medium $\left(\mathbf{y}_{\mathbf{2}}\right)$ & Low $\left(\mathbf{y}_{\mathbf{3}}\right)$ \\
\hline Accelerated Learning Cycle & $\mathrm{xy}_{11}$ & $\mathrm{xy}_{12}$ & $\mathrm{xy}_{13}$ \\
Brain-based learning model & $\mathrm{xy}_{21}$ & $\mathrm{xy}_{22}$ & $\mathrm{xy}_{23}$ \\
Direct Instruction & $\mathrm{xy}_{31}$ & $\mathrm{xy}_{32}$ & $\mathrm{xy}_{33}$ \\
\hline
\end{tabular}

With $\mathrm{xy}_{\mathrm{ij}}$ is the value of the learning model (i) and the mathematical communication ability (j), $i=1,2,3$ and $j=1,2,3$.

Documentation method was used to investigate the students' mathematics data in the previous year. The test was also used to collect reasoning ability data and mathematical communication abilities in the form of multiple-choice tests which consisted of 25 items for the 
mathematical reasoning test and 7 items the mathematical communication test. The mathematical reasoning ability test scores were analyzed using a two-way analysis of variance with unequal cells with an error level of 5\%. Hypothesis testing was aimed at finding out whether there is an influence between each learning model, each ability category of students' mathematical communication, and interactions between the two can be seen in the results of mathematical reasoning abilities.

\section{RESULTS AND DISCUSSION}

The results of the prerequisite test allowed the use of two-way ANOVA with unequal cells with a significance level of 5\%. The result of hypothesis testing can be seen in Table 2 .

Table 2. The Results of Two-Way ANOVA

\begin{tabular}{lccccc}
\hline \multicolumn{1}{c}{ Source } & $\mathrm{JK}$ & $\mathrm{dk}$ & $\mathrm{RK}$ & \multicolumn{1}{c}{$\mathrm{F}_{\text {obs }}$} & $\mathrm{F}_{\alpha}$ \\
\hline Learning model (X) & 5618.16 & 2 & 2809.08 & 12.99 & 3.00 \\
Communication ability (Y) & 7856.34 & 2 & 3928.17 & 18.16 & 3.00 \\
Interaction (XY) & 2606.31 & 4 & 651.58 & 3.02 & 2.37 \\
Error (G) & 62541.38 & 289 & 216.42 & & \\
Total & 78622.15 & 297 & & & \\
\hline
\end{tabular}

The results of the calculation of $\mathrm{F}_{\mathrm{obs}}$ for $\mathrm{H}_{0 \mathrm{X}}, \mathrm{H}_{0 \mathrm{Y}}$, and $\mathrm{H}_{0 \mathrm{XY}}$ shown in Table 2 can be concluded were rejected. Based on the test decision, it can be concluded that: (1) learning model influences mathematical reasoning ability, (2) mathematical communication ability influences mathematical reasoning, (3) there is an interaction between learning models and mathematical communication ability on mathematical ability. Since the $\mathrm{H}_{0 \mathrm{X}}, \mathrm{H}_{0 \mathrm{Y}}$, and $\mathrm{H}_{0 \mathrm{XY}}$ were rejected, it is necessary to do a post-ANOVA test using the Scheffe' method, namely inter-row average comparison test, inter-column average comparison test, and inter-cell average comparison test. The results are presented in Table 3.

Table 3. The Summary of Inter-row Double Comparisons

\begin{tabular}{cccc}
\hline$H_{0}$ & $F_{o b s}$ & $2 F_{\alpha ; v}$ & Decision \\
\hline$\mu_{1 .}=\mu_{2 .}$ & 10.49 & (2) $(3.00)=6.00$ & $H_{0}$ is rejected \\
$\mu_{2 .}=\mu_{3 .}$ & 34.33 & (2) $(3.00)=6.00$ & $H_{0}$ is rejected \\
$\mu_{1 .}=\mu_{3 .}$ & 6.20 & (2) $(3.00)=6.00$ & $H_{0}$ is rejected \\
\hline
\end{tabular}

By comparing $\mathrm{F}_{\mathrm{obs}}$ with critical value, it appears that there are significant differences between the $\mu_{1}$. and $\mu_{2 .}, \mu_{3}$ and $\mu_{3}$. By paying attention to the marginal average, it can be concluded that: (1) the Accelerated Learning Cycle is better than the Brain-based learning model and Direct Instruction and the Brain-based learning model is better than Direct Instruction. The result of the inter-column multiple comparison test is presented in Table 4.

Table 4. The Summary of Inter-Column Double Comparisons

\begin{tabular}{cccc}
\hline$H_{0}$ & $F_{o b s}$ & $2 F_{\alpha ; v}$ & Decision \\
\hline$\mu_{.1}=\mu_{.2}$ & 14.59 & (2) $(3.00)=6.00$ & $H_{0}$ is rejected \\
$\mu_{.2}=\mu_{.3}$ & 38.53 & (2) $(3.00)=6.00$ & $H_{0}$ is rejected \\
$\mu_{.1}=\mu_{.3}$ & 7.13 & (2) $(3.00)=6.00$ & $H_{0}$ is rejected \\
\hline
\end{tabular}

By comparing $\mathrm{F}_{\text {obs }}$ with critical values, it appears that there is a significant difference between $\mu_{.1}$ and $\mu_{.2}, \mu_{.2}$ and $\mu_{.3}$, as well as $\mu_{.1}$ and $\mu_{.3}$. By paying attention to the marginal mean of each column, it can be concluded that: (1) students with high mathematical communication abilities have better mathematical reasoning abilities than students with moderate mathematical 
communication abilities because the average scores of students with high mathematical communication abilities were 69.17 while the average scores of students with moderate mathematical communication abilities were 61.12. (2) students with high mathematical communication abilities have better mathematical reasoning abilities than students with low mathematical communication abilities because the average scores of the student with high mathematical communication abilities were 69.17 while the average scores of students with low mathematical communication abilities were 55.71, and (3) students with moderate mathematical communication abilities have better mathematical reasoning abilities than students with low mathematical communication abilities because the average scores of the student with moderate mathematical communication abilities were 61.12 while the average scores of students with low mathematical communication abilities were 55.71.

In the double cell intercomparison test the results are obtained as presented in Table 5.

Table 5. The Summary of Inter-cell Double Comparisons

\begin{tabular}{cccc}
\hline $\mathrm{H}_{0}$ & $\mathrm{~F}_{\text {obs }}$ & $8 \mathrm{~F}_{\alpha ; \mathrm{v}}$ & Decision \\
\hline$\mu_{11}=\mu_{21}$ & 14.05 & $(8)(1.95)=15.6$ & $H_{0}$ is accepted \\
$\mu_{11}=\mu_{31}$ & 4.04 & $(8)(1.95)=15.6$ & $H_{0}$ is accepted \\
$\mu_{21}=\mu_{31}$ & 1.23 & $(8)(1.95)=15.6$ & $H_{0}$ is accepted \\
$\mu_{12}=\mu_{22}$ & 1.00 & $(8)(1.95)=15.6$ & $H_{0}$ is accepted \\
$\mu_{12}=\mu_{32}$ & 3.69 & $(8)(1.95)=15.6$ & $H_{0}$ is accepted \\
$\mu_{22}=\mu_{32}$ & 0.80 & $(8)(1.95)=15.6$ & $H_{0}$ is accepted \\
$\mu_{13}=\mu_{23}$ & 2.05 & $(8)(1.95)=15.6$ & $H_{0}$ is accepted \\
$\mu_{13}=\mu_{33}$ & 22.44 & $(8)(1.95)=15.6$ & $H_{0}$ is rejected \\
$\mu_{23}=\mu_{33}$ & 9.83 & $(8)(1.95)=15.6$ & $H_{0}$ is accepted \\
$\mu_{11}=\mu_{12}$ & 11.12 & $(8)(1.95)=15.6$ & $H_{0}$ is accepted \\
$\mu_{11}=\mu_{13}$ & 12.3 & $(8)(1.95)=15.6$ & $H_{0}$ is accepted \\
$\mu_{12}=\mu_{13}$ & 0.07 & $(8)(1.95)=15.6$ & $H_{0}$ is accepted \\
$\mu_{21}=\mu_{22}$ & 0.26 & $(8)(1.95)=15.6$ & $H_{0}$ is accepted \\
$\mu_{21}=\mu_{23}$ & 1.61 & $(8)(1.95)=15.6$ & $H_{0}$ is accepted \\
$\mu_{22}=\mu_{23}$ & 0.62 & $(8)(1.95)=15.6$ & $H_{0}$ is accepted \\
$\mu_{31}=\mu_{32}$ & 5.38 & $(8)(1.95)=15.6$ & $H_{0}$ is accepted \\
$\mu_{31}=\mu_{33}$ & 24.55 & $(8)(1.95)=15.6$ & $H_{0}$ is rejected \\
$\mu_{32}=\mu_{33}$ & 12.06 & $(8)(1.95)=15.6$ & $H_{0}$ is accepted \\
\hline
\end{tabular}

Based on the test in Table 5, it can be concluded that: (1) $\mathrm{H}_{0}: \mu_{11}=\mu_{21}, \mathrm{H}_{0}: \mu_{11}=\mu_{31}$, and $\mathrm{H}_{0}: \mu_{21}=\mu_{31}$, the test decision declares that $\mathrm{H}_{0}$ is accepted. This means that at high mathematical communication abilities, the Accelerated Learning Cycle, Brain-based learning model, and Direct Instruction provide equally good mathematical reasoning abilities, (2) at $\mathrm{H}_{0}: \mu_{12}=\mu_{22}, \mathrm{H}_{0}: \mu_{12}=\mu_{32}$, and $\mathrm{H}_{0}: \mu_{22}=\mu_{32}$, the test decision declares that $\mathrm{H}_{0}$ is accepted. This means that in the medium mathematical communication abilities, the Accelerated Learning Cycle, Brain-based learning model, and Direct Instruction provide equally good mathematical reasoning abilities, (3) at $\mathrm{H}_{0}: \mu_{13}=\mu_{23}$ andH $\mathrm{H}_{0}: \mu_{23}=\mu_{33}$, the test decision declares that $\mathrm{H}_{0}$ is accepted. This means that at low mathematical communication abilities, the Accelerated Learning Cycle, Brain-based learning model, and Direct Instruction provide the same mathematical reasoning ability, and (4) at $\mathrm{H}_{0}: \mu_{13}=\mu_{33}$, the test decision declares that $\mathrm{H}_{0 \mathrm{~s}}$ is rejected. This means that at low mathematical communication abilities, the Accelerated Learning Cycle provides better mathematical reasoning ability than Direct Instruction because by looking at the average of each cell, the Accelerated Learning Cycle is at 63.66 while in the 
Direct Instruction is at 46.84. (5) At $\mathrm{H}_{0}: \mu_{11}=\mu_{12}, \mathrm{H}_{0}: \mu_{11}=\mu_{13}$, and $\mathrm{H}_{0}: \mu_{12}=\mu_{13}$, the test decision declares that $\mathrm{H}_{0}$ is accepted. This means that in the Accelerated Learning Cycle, students with high, medium, and low mathematical communication abilities have the same good mathematical reasoning abilities, (6) at $\mathrm{H}_{0}: \mu_{21}=\mu_{22}, \mathrm{H}_{0}: \mu_{21}=\mu_{23}$, and $\mathrm{H}_{0}: \mu_{22}=\mu_{23}$, the test decision declares that $\mathrm{H}_{0}$ is accepted. This means that in the Brain-based learning model, students with high, medium, and low mathematical communication abilities have the same mathematical reasoning abilities, (7) at $\mathrm{H}_{0}: \mu_{31}=\mu_{32}$ and $\mathrm{H}_{0}: \mu_{32}=\mu_{33}$, the test decision declares that $\mathrm{H}_{0}$ is received. This means that in the Direct Instruction, students with high mathematical communication abilities have the same mathematical reasoning abilities as students with moderate mathematical communication abilities and students with moderate mathematical communication abilities have the same mathematical reasoning abilities as students with low mathematical communication abilities, (8) at $\mathrm{H}_{0}: \mu_{31}=\mu_{33}$, the test decision declares that $\mathrm{H}_{0}$ is rejected. This means that in the Direct Instruction, students with high mathematical communication abilities have better mathematical reasoning abilities than students with low mathematical communication abilities because by looking at the average of each cell, the students with high mathematical communication abilities are at 67.78 while students with low mathematical communication abilities are at 46.84 .

The result of this research is relevant with several studies which indicate that there is an effect of Accelerated Learning Cycles on the ability to solve mathematical problems for all students $(p=0,000, p<0.05)$ and all initial mathematical abilities categories (Amelia, 2015). Other researchers also state that students who learn mathematics learning through the Accelerated Learning Cycle are better than students who learn mathematics through conventional models (Muligar, 2016). The results of other studies also explain the use of a Brain-based learning model that can improve students' critical thinking abilities (Wisudawati, 2014). According to the results of other studies, the Brain-based learning model increases student learning motivation and students' mathematical connection abilities.

The results of the study are following the second hypothesis that students with high mathematical communication abilities have better learning outcomes than students with moderate and low mathematical communication abilities and students with moderate mathematical communication abilities have better learning outcomes than students with low mathematical communication abilities. It is supported by other research that shows students with high mathematical communication abilities have better learning outcomes than students with moderate and low mathematical communication abilities and students with moderate mathematical communication abilities have better mathematics learning outcomes than students with low mathematical communication abilities. The results of other studies are relevant to the third hypothesis which states that there is an interaction between learning models and students' mathematical communication abilities and learning outcomes although not all are relevant to the third hypothesis.

\section{CONCLUSIONS}

Based on the results of research and discussion, it can be concluded that: (1) the Accelerated Learning Cycle results in better mathematical reasoning abilities than the Brain-based learning model and Direct Instruction learning models and the Brain-based learning model provides is better than the Direct Instruction, (2) students with high mathematical communication abilities 
have better mathematical reasoning than students with moderate and low mathematical communication abilities and students with moderate mathematical communication abilities have a better mathematical reasoning ability than students with low mathematical communication abilities.

Based on the findings obtained in this study, the Accelerated Learning Cycle and Brainbased learning model can be applied since they can improve mathematical reasoning abilities better. Besides, researchers also suggest the other researchers be able to conduct further research in the form of developing Accelerated Learning Cycle and Brain-based learning model by paying attention to the characteristics of other students adjusted to the school curriculum.

\section{AUTHOR CONTRIBUTIONS STATEMENT}

APK is the drafter of this research. This study was designed, conceptualized and carried out by him and assisted by NKR. They have made major contributions in designing the theoretical framework and reviewing the literature related to research. $\mathrm{R}$ becomes an important part in the process of developing articles for the better.

\section{REFERENCES}

Adesty, M., Nurhanurawati, \& Widyastuti. (2014). Pengaruh model pembelajaran kooperatif tipe nht terhadap kemampuan komunikasi matematis dan belief. Jurnal Pendidikan Matematika Unila, 2(2).

Ambarwati, R., Dwijanto, D. \& Hendikawati, P. (2015). Keefektifan model project-based learning berbasis GQM terhadap kemampuan komunikasi matematis dan percaya diri siswa kelas VII. Unnes Journal of Mathematics Education, 1(1), 180-186.

Amelia, S. (2015). Pengaruh accelerated learning cycle terhadap kemampuan pemecahan masalah matematis siswa SMP. Jurnal Pengajaran MIPA, 20(2), 122-124.

Andrianti, R. Y., Irawati, R., \& Sudin, A. (2016). Pengaruh pendekatan SAVI (somatic, auditory, visual, intellectual) dalam meningkatkan kemampuan komunikasi matematis dan motivasi belajar siswa sekolah dasar pada materi pengolahan data. Jurnal Pena Ilmiah, 1(1), 471-480.

Ariany, R. L., \& Dahlan, J. A. (2017). Penerapan strategi pembelajaran multiple intelligences (MI) untuk meningkatkan kemampuan penalaran dan disposisi matematis siswa SMP. JES-MAT (Jurnal Edukasi Dan Sains Matematika), 3(1), 1-10.

Atsnan, M. F. (2016). Pengembangan perangkat pembelajaran vektor dengan pendekatan creative problem solving kelas XI SMK Teknokestan. Jurnal Riset Pendidikan Matematika, 3(1), 66-75.

Awaliyah, H. F. (2016). Peningkatan prestasi belajar al kitabah dengan model accelerated learning menggunakan pendekatan savi pada siswa kelas VIIIa MTs negeri Sleman. Al Mahara : Jurnal Pendidikan Bahasa Arab, 22(7), 305-326.

Badrun, B. \& Hartono, H. (2013). Keefektifan metode pembelajaran kooperatif model STAD ditinjau dari prestasi dan motivasi belajar siswa di kelas VIII SMP. PYTHAGORAS: Jurnal Pendidikan Matematika, 8(2), 120-134. 
Diandita, E. R., Johar, R., \& Abidin, T. F. (2017). Kemampuan komunikasi matematis dan metakognitif siswa smp pada materi lingkaran berdasarkan gender. Jurnal Pendidikan Matematika, 11(2), 79-97.

Fisher, D. (2017). Peningkatan kemampuan penalaran matematis mahasiswa calon guru matematika melalui blended-learning dengan strategi probing-prompting. Symmetry: Pasundan Journal of Research in Mathematics Learning and Education, 2(2), 1-9.

Harahap, S. Z. H. (2014). Peningkatan kemampuan penalaran logis dan komunikasi matematis melalui model pembelajaran kooperatif tipe think pair share (TPS) di SMP negeri 24 Medan. (Doctoral dissertation, UNIMED).

Hartati, T., \& Suyitno. (2015). Studi komparatif model pembelajaran TAI dan CIRC terhadap kemampuan komunikasi matematis siswa. Unnes Journal of Mathematics Education, $4(1), 60-68$.

Indriani, L. F. (2018). Kemampuan penalaran matematis dan habits of mind siswa SMP dalam materi segiempat dan segitiga. Jurnal Math Educator Nusantara, 4(2), 87-94.

Khamid, A., \& Santosa, R. H. (2016). Keefektifan pendekatan PBL dan CTL ditinjau dari komunikasi matematis dan motivasi belajar siswa SMP. PYTHAGORAS: Jurnal Pendidikan Matematika, 11(2), 111-122.

Muligar, R. (2016). Penerapan model pembelajaran accelerated learning cycle untuk meningkatkan kemampuan berpikir kritis dan representasi matematis serta mengurangi kecemasan matematis ditinjau dari perbedaan gender siswa SMP. (Doctoral dissertation, UNPAS).

Nopitasari, D. (2015). Pengaruh model pembelajaran creative problem solving (CPS) terhadap kemampuan penalaran adaptif matematis siswa. MaTHLINE: Jurnal Matematika dan Pendidikan Matematika, 1(1), 103-112.

Nurhayati, N. (2018). Pengembangan perangkat bahan ajar pada pembelajaran matematika realistik indonesia untuk meningkatkan kemampuan komunikasi matematis siswa. Fibonacci : Jurnal Pendidikan Matematika Dan Matematika, 3(2), 121-136.

Nuriadin, I. (2015). Pembelajaran kontekstual berbantuan program geometer's sketchpad dalam meningkatkan kemampuan koneksi dan komunikasi matematis siswa SMP. Jurnal Ilmiah Program Studi Matrmatika STKIP Siliwangi Bandung, 4(2), 168-181.

Putra, F. G. (2016). Pengaruh model pembelajaran reflektif dengan pendekatan matematika realistik bernuansa keislaman terhadap kemampuan komunikasi matematis. Al-Jabar: Jurnal Pendidikan Matematika, 7(2), 203-210.

Putra, R. W. Y. (2015). Pembelajaran konflik kognitif untuk meningkatkan kemampuan komunikasi matematis siswa berdasarkan kategori pengetahuan awal matematis SMA. AlJabar: Jurnal Pendidikan Matematika, 6(2), 155-166.

Sari, F. K., Farida, \& Syazali, M. (2016). Pengembangan media pembelajaran (modul) berbantuan geogebra pokok bahasan turunan. Al-Jabar: Jurnal Pendidikan Matematika, $7(2), 135-151$.

Setiawan, A. (2016). Hubungan kausal penalaran matematis terhadap prestasi belajar matematika pada materi bangun ruang sisi datar ditinjau dari motivasi belajar siswa. $\mathrm{Al}$ - 
Jabar: Jurnal Pendidikan Matematika, 7(1), 91-100.

Solekha, F. N., Noer, S. H., \& Gunowibowo, P. (2013). Pengaruh model pembelajaran kooperatif tipe group investigation terhadap kemampuan komunikasi matematis siswa. Jurnal Pendidikan Matematika Unila, 1(9), 1-11.

Sumartini, T. S. (2018). Peningkatan kemampuan penalaran matematis siswa melalui pembelajaran berbasis masalah. Mosharafa: Jurnal Pendidikan Matematika, 4(1), 1-10.

Supriadi, N., \& Damayanti, R. (2016). Analisis kemampuan komunikasi matematis siswa lamban belajar dalam menyelesaikan soal bangun datar. Al-Jabar: Jurnal Pendidikan Matematika, 7(1), 1-9.

Syazali, M. (2015). Pengaruh model pembelajaran creative problem solving berbantuan maple II terhadap kemampuan pemecahan masalah matematis. Al-Jabar: Jurnal Pendidikan Matematika, 6(1), 91-98.

Wibowo, A. (2017). Pengaruh pendekatan matematika realistik dan saintifik terhadap prestasi belajar, kemampuan penalaran matematis dan minat belajar. Jurnal Riset Pendidikan Matematika, 4(1), 1-10.

Wisudawati, A. (2014). Penerapan pembelajaran fisika berdasarkan strategi brain based learning untuk meningkatkan keterampilan berpikir kritis siswa pada materi elastisitas kelas XI di SMA negeri 1 Wonoayu Sidoarjo. Inovasi Pendidikan Fisika, 3(2), 1-5.

Wulandari, P., Mujib, M., \& Putra, F. G. (2016). Pengaruh model pembelajaran investigasi kelompok berbantuan perangkat lunak maple terhadap kemampuan pemecahan masalah matematis. Al-Jabar: Jurnal Pendidikan Matematika, 7(1), 101-106.

Zakaria, E., \& Iksan, Z. (2007). Promoting cooperative learning in science and mathematics education: A malaysian perspective. Online Submission, 3(1), 35-39. 